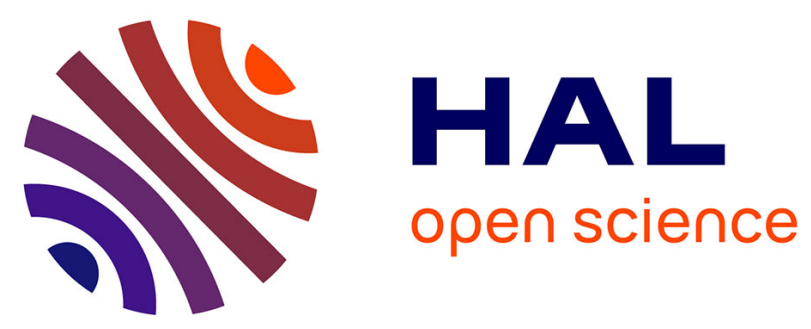

\title{
TRITERPENOIDS FROM BALSAMS: USEFUL MARKERS TO RECOGNIZE GENUINE, ADULTERATED AND ARCHAEOLOGICAL RESINS
}

Blandine Courel, Pierre Adam, Philippe Schaeffer

\section{- To cite this version:}

Blandine Courel, Pierre Adam, Philippe Schaeffer. TRITERPENOIDS FROM BALSAMS: USEFUL MARKERS TO RECOGNIZE GENUINE, ADULTERATED AND ARCHAEOLOGICAL RESINS. 29th International Meeting on Organic Geochemistry (IMOG), Sep 2019, Gothenburg, Sweden. 2019. hal-03045353

\author{
HAL Id: hal-03045353 \\ https://hal.science/hal-03045353
}

Submitted on 7 Dec 2020

HAL is a multi-disciplinary open access archive for the deposit and dissemination of scientific research documents, whether they are published or not. The documents may come from teaching and research institutions in France or abroad, or from public or private research centers.
L'archive ouverte pluridisciplinaire HAL, est destinée au dépôt et à la diffusion de documents scientifiques de niveau recherche, publiés ou non, émanant des établissements d'enseignement et de recherche français ou étrangers, des laboratoires publics ou privés. 
TRITERPENOIDS FROM BALSAMS: USEFUL MARKERS TO RECOGNIZE GENUINE, ADULTERATED AND ARCHAEOLOGICAL RESINS

\author{
B. Courel $^{\ddagger}$, P. Adam, P. Schaeffer \\ Université de Strasbourg-CNRS, UMR 7177, Strasbourg, France \\ ‡Present address: The British Museum, London, United Kingdom
}

\title{
Introduction
}

Balsams are resinous exudates from plant species of the genera Styrax (Styracaceae), Liquidambar (Altingiaceae, formerly included within Hamamelidaceae) and Myroxylon (Fabaceae), which have been exploited since the Neolithic for their pleasant scent and medicinal properties (Solazzo et al., 2016). They are characterized by the presence of abundant aromatic compound series belonging predominantly to the cinnamate and benzoate ester families 1 and 2 (numbers refer to structures in Figure 1). These compounds, which can in principle be used to assess the botanical source of balsams are, however, very sensitive to degradative processes during exposure to environmental conditions (Solazzo et al., 2016), making them unusable as chemotaxonomic biomarkers in the case of altered archaeological balsams. More reliable biomarkers which can be used to unambiguously identify the botanical source of archaeological balsams, even in the case of severely altered samples, are therefore needed. Comparative lipid analysis of various extant balsams (Styrax officinalis, $S$. paralleloneurum, S. tonkinensis, Liquidambar styraciflua, L. orientalis and Myroxylon balsamum var. pereirae) has thus been carried out using gas chromatography-mass spectrometry (GC-MS) to explore, in particular, the potential of triterpenoids as chemotaxonomic indicators. Triterpenoids, which could indeed be successfully used for the characterisation of various resinous archaeological materials (other than balsams) comprising frankincense (e.g., Brettell et al., 2015), Pistacia resin (e.g., Stern et al., 2003) and birch bark tar (e.g., Courel et al., 2018), can be considered as more reliable markers than benzoates/cinnamates. Up to now, only few studies were dedicated to the triterpene composition of balsams (e.g., Hovaneissian et al., 2008).

\section{Results}

GC-MS investigation of the triterpenoids from $S$. officinalis, $S$. paralleloneurum and $S$. tonkinensis resins showed that they mainly belong to the oleanane family, including relatively common triterpenoids such as oleanolic and oleanonic acids $\mathbf{3}$ and $\mathbf{4}$. Interestingly, a series of uncommon 6-oxygenated derivatives of oleanolic acid comprising sumaresinolic acid $\mathbf{5 a}$ and the related ketones $\mathbf{5 b}$ and $\mathbf{5} \mathbf{c}$ was identified solely in the styrax resins and could therefore be specifically related to these exudates. The same compound series, together with related degradation products and degraded benzoate/cinnamate derivatives, could be unambiguously identified in an archaeological styrax resin (Solazzo et al., 2016). Investigation of triterpenoids from balsams potentially also allows discrimination of styrax resins at the species level to be made, since, for instance, siaresinolic acid $\mathbf{6}$ could be exclusively detected in $S$. tonkinensis, along with the 6-oxygenated triterpenoids 5a-c common to all Styracaceae resins.

Liquidambar gums from $L$. styraciflua and $L$. orientalis are characterised by the predominance of oleanonic acid 4 together with uncommon 3-epi oleanolic 7 and ursolic 8 acids. Such an assemblage has not been found in other balsams and can thus be considered as characteristic of liquidambar resins. 
The resin from M. balsamum var. pereirae (Peru balsam) was very rich in cinnamic and benzoic acids, but devoid of triterpenoids.

a.<smiles>[R]OC(=O)/C=C/c1ccccc1</smiles>

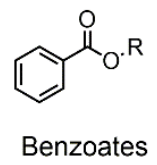

2 b.

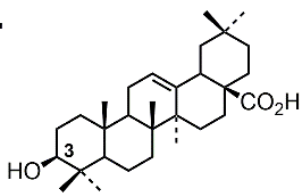

3

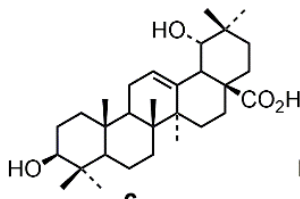

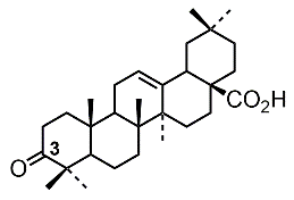

4

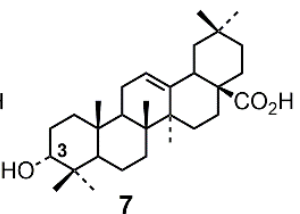

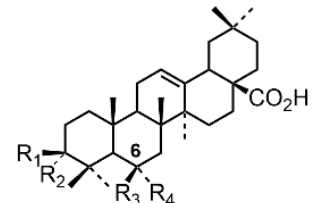

5a: $\mathrm{R}_{1}=\mathrm{OH}, \mathrm{R}_{2}=\mathrm{H} ; \mathrm{R}_{3}=\mathrm{OH}, \mathrm{R}_{4}=\mathrm{H}$ 5b: $R_{1}, R_{2}=O ; R_{3}=O H, R_{4}=H$ 5C: $R_{1}=O H, R_{2}=H ; R_{3}, R_{4}=0$

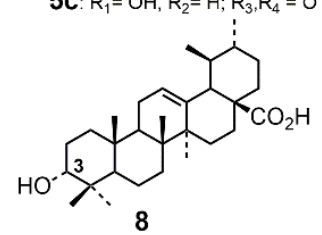

Figure 1: Structures of (a) cinnamate and benzoate esters and (b) triterpenoids from balsams

\section{Conclusions}

The results obtained reveal that, even in the case of extended alteration/removal of cinnamic and benzoic acid derivatives, as might be the case for altered archaeological samples (e.g., Solazzo et al., 2016), styrax resins can be identified using the triterpenoid assemblage, and a distinction between balsams from Styrax. sp, Liquidambar sp. and Myroxylon sp. remains possible based on the distribution of these triterpenoids. These results offer new promising perspectives for the characterization of resins and unguents found in an archaeological context as it might also find an application for the detection of counterfeit/adulterated balsams which are widespread on the market.

\section{References}

Brettell, R.C., Schotsmans, E.M.J., Walton Rogers, P., Reifarth, N., Redfern, R.C., Stern, B., Heron, C.P., 2015. "Choicest unguents": molecular evidences for the use of resinous plant exudates in late Roman mortuary rites in Britain. Journal of Archaeological Science 53, 639-648.

Courel, B., Schaeffer, P., Féliu, C., Thomas, Y., Adam, P., 2018. Birch bark tar and jewellery: the case study of a necklace from the Iron age (Eckwersheim, NE France). Journal of Archaeological Science: Reports 20, 72-79.

Hovaneissian, M., Archier, P., Mathe, C., Culioli, G., Vieillescazes, C., 2008, Analytical investigation of styrax and benzoin balsams by HPLC-PAD-fluorimetry and GC-MS. Phytochemical Analysis 19, 301-310.

Solazzo, C., Courel, B., Connan, J., van Dongen, B.E., Barden, H., Penkman, K., Taylor, S., Demarchi, S., Adam, P., Schaeffer, P., Nissenbaum, A., Bar-Yosef, O., Buckley, M., 2016. Identification of the earliest collagen and plant-based coatings from Neolithic artefacts (Nahal Hemar cave, Israel). Scientific Reports 6:31053 DOI:10.1038/srep31053.

Stern, B., Heron, C., Corr, L., Serpico, M., Bourriau, J., 2003. Compositional variations in aged and heated Pistacia resin found in Late Bronze Age canaanite amphorae and bowls from Amarna, Egypt. Archaeometry 45, 457-469. 